\title{
RESEARCH
}

\section{Exploring Electronic Communication Modes Between Iraqi Faculty and Students of Pharmacy Schools Using the Technology Acceptance Model}

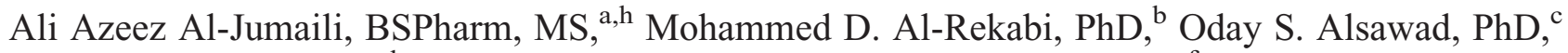 \\ Omer Q.B. Allela, PhD, ${ }^{\mathrm{d}}$ Ryan Carnahan, PharmD, MS, ${ }^{\mathrm{e}}$ Hiwa Saaed, PhD, ${ }^{\mathrm{f}}$ Alaadin Naqishbandi, PhD, ${ }^{\mathrm{g}}$ \\ Dheyaa J. Kadhim, PhD, ${ }^{\text {h }}$ Bernard Sorofman, $\mathrm{PhD}^{\mathrm{a}}$ \\ ${ }^{a}$ University of Iowa College of Pharmacy, Iowa City, Iowa \\ ${ }^{\mathrm{b}}$ University College of Humanities Faculty of Pharmacy, Kufa, Al-Najaf, Iraq \\ ${ }^{\mathrm{c}}$ University of Basrah College of Pharmacy, Basrah, Iraq \\ ${ }^{\mathrm{d}}$ University of Duhok College of Pharmacy, Duhok, Kurdistan, Iraq \\ ${ }^{\mathrm{e}}$ University of Iowa College of Public Health, Iowa City, Iowa \\ ${ }^{\mathrm{f}}$ University of Sulaimani College of Pharmacy, Sulaymaniyah, Kurdistan, Iraq \\ ${ }^{g}$ Hawler Medical University College of Pharmacy, Erbil, Kurdistan, Iraq \\ ${ }^{\mathrm{h}}$ University of Baghdad College of Pharmacy, Baghdad, Iraq
}

Submitted March 24, 2016; accepted August 22, 2016; published June 2017.

Objective. To explore for the first time the extent to which Iraqi pharmacy students and faculty use Facebook and university email for academic communications, and to examine factors influencing utilization within the framework of the Technology Acceptance Model (TAM).

Methods. An electronic survey was administered to convenience samples of students and faculty of six Iraqi public schools and colleges of pharmacy in 2015.

Results. Responses included 489 student and 128 faculty usable surveys. Both students and faculty use Facebook more than university email for academic communications. Less than a third of the faculty used university email. Students used Facebook for academic purposes twice as much as faculty.

Conclusion. Absence of university email in Iraqi schools and colleges of pharmacy makes Facebook essential for faculty-student communications. The majority $(71.1 \%$ to $82 \%)$ of respondents perceived that Facebook was easy to use. Three TAM variables (intention to use, attitude toward use and perceived usefulness) had significant positive associations with actual use of both Facebook messaging and university email.

Keywords: Facebook, email, college, students, faculty

\section{INTRODUCTION}

Information and communication technologies (ICTs) include any communication device or application, such as smartphones, tablets, computers, videos, distance learning, network hardware and software, and others. ${ }^{1}$ Electronic communications save time and effort. Iraqi universities are still developing electronic communications, particularly in circumstances related to instructor-student electronic communications. For instance, most Iraqi universities have not adopted university official email or other web-based communication systems. Iraqi universities have neither implemented Electronic Course Management Systems

Corresponding Author: Ali Azeez Al-Jumaili, University of Iowa College of Pharmacy, 115 S. Grand Ave., S532 PHAR, Iowa City, IA 52242. Tel: 319-936-4354. Fax: 319-353-5646. E-mail: aliazeezali-aljumaili@uiowa.edu nor fully activated university email. At most Iraqi universities, only faculty members have university email accounts. However, most faculty members do not have their students' academic email addresses because students are not provided with academic email accounts. Even among faculty members, using one's university email account remains unpopular. In contrast, Facebook, which started in 2004, is very popular and rapidly spreading as a social network site in Iraq. Hence, some faculty members have been using their personal Facebook account for academic purposes, such as informing their students about important upcoming school events. Moreover, many students use Facebook to ask their professors academicrelated questions. According to the Arab Social Media Report (2015), 88\% of social media users in Iraq have a Facebook account and $99 \%$ of Facebook subscribers have daily access to their accounts. ${ }^{2}$ 


\section{American Journal of Pharmaceutical Education 2017; 81 (5) Article 89.}

\section{Literature Review}

Facebook can improve the learning experience of students through communication with teachers and classmates in addition to sharing academic materials. ${ }^{3}$ Roblyer and colleagues concluded that college students are more willing to use Facebook for academic purposes than faculty members. ${ }^{4}$ Hall and colleagues found that $91.8 \%$ of pharmacy students in the UK used social media. ${ }^{5}$ Given the increased use of technology for teaching purposes, many studies have looked at the impact of different forms of technologies on academic progress. Kim and colleagues reported on other studies that concluded that adapting technology improves teaching and learning processes. Technology like computer-based testing was suggested because it was easy to use and economical. ${ }^{6}$ One Iranian study demonstrated that almost all faculty members believed that ICTs are much better than traditional means of education. ${ }^{1}$ An Australian study found that integrating ICTs into academic programs provides many benefits for both college students and faculty. For instance, ICTs provide fast and convenient access to information, improve communication, enhance student in-class participation, facilitate distance education, and help students review class materials. ${ }^{7}$ A study covering six schools and colleges of pharmacy across the US showed that the vast majority of faculty members (86\%) and students (91\%) agreed that adoption of technology such as course management systems and lecture capture satisfied their needs. ${ }^{8}$ Mazer and colleagues explored faculty self-disclosure (using narratives and humor) via Facebook on college student motivation. ${ }^{9}$ They found that students who had access to high self-disclosed faculty Facebook profiles had a high level of motivation, active learning and positive classroom learning. ${ }^{9}$

\section{Theoretical Framework}

In 1989, Davis and colleagues introduced the Technology Acceptance Model (TAM), which posits factors predicting the acceptability of information technologies. The TAM has been used to explore the factors influencing health care provider acceptance to use new technologies. ${ }^{10}$ The independent factors include Perceived Usefulness (PU), Perceived Ease of Use (PEU), Attitude Toward Using (ATU) and Behavioral Intention to Use (BIU). In our study, the technologies were Facebook and university email. The outcome variables included the use of these technologies for academic purposes. Perceived usefulness (PU) means faculty members believe that adopting information technology improves their teaching and students perceive that using Facebook for academic purposes enhances their learning. Perceived ease of use (PEU) refers to faculty belief that adopting a new technology will not require much effort. The TAM proposes that intention to use directly influences the actual use of information technology. Perceived usefulness of technology directly affects attitude toward using and intention to use. Perceived ease of technology use directly influences perceived usefulness and attitude toward using (Figure 1).

Teo in 2011 had modified TAM by adding another construct, which is facilitating conditions (FC), to measure factors influencing teachers' intention to use technologies. ${ }^{11}$ Facilitating conditions is the extent to which an individual believes that technical support and facilities are available in the setting to facilitate adoption of a new technology (Figure 1). Teo proved that the FC has a significant direct effect on the outcome (Actual Technology Use-ACU) and an indirect effect through influencing BIU and PEU. ${ }^{11}$ Teo demonstrated that variability in technology use was much better explained by the TAM when FC was added as a predictor, such that TAM explained $61 \%$ of the variance in actual technology use. ${ }^{11}$ Individual characteristics may also influence technology use, so we also evaluated these as predictors (Figure 1).

We conducted this study in six Iraqi public universities, which are fully government funded and provide

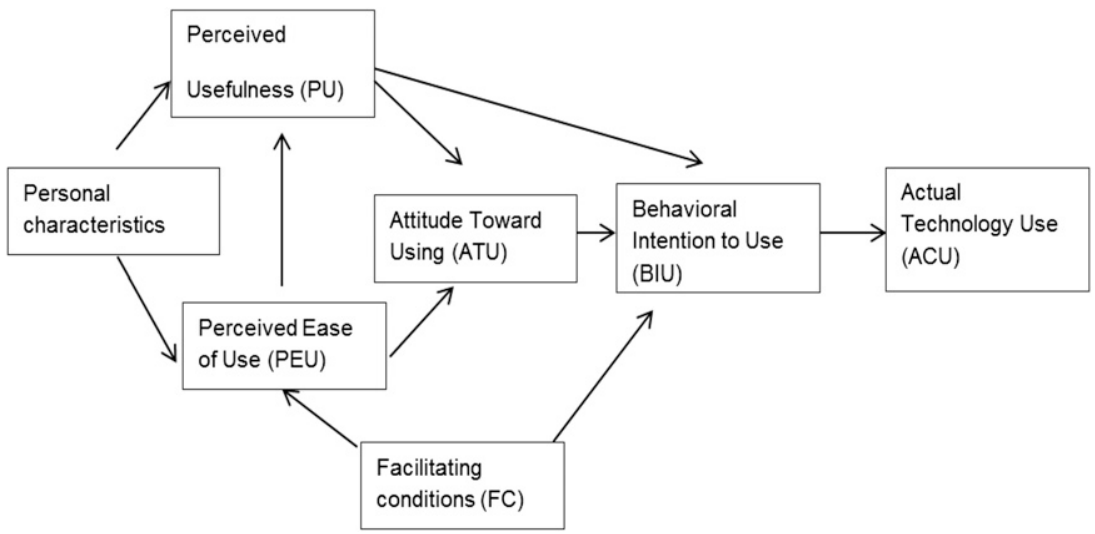

Figure 1. Modified Technology Acceptance Model. ${ }^{11,17}$ Reprinted with permission from the Institute for Operations Research and the Management Sciences. 


\section{American Journal of Pharmaceutical Education 2017; 81 (5) Article 89.}

free education. All Iraqi colleges of pharmacy offer fiveyear bachelor programs according to the regulations of the Iraqi Ministry of Higher Education.

Investigators have studied perceptions about adoption of communication and information technologies at American universities for more than a decade. However, to our knowledge no prior research has evaluated university-level instructor-student electronic communication using the Technology Acceptance Model (TAM). Our study is unique in using TAM to explore factors influencing ICTs acceptance by students and faculty members at schools and colleges of pharmacy in Iraq. This study aimed to explore for the first time the extent to which Iraqi pharmacy students and faculty members use Facebook and university email for daily academic communication. A second aim was to examine the factors influencing the utilization of Facebook and university email for academic purposes on national level using TAM.

\section{METHODS}

This was a cross-sectional descriptive study in six public universities in six different Iraqi provinces. We conducted a survey using the instruments developed from the Technology Acceptance Model (TAM) (Table 3). It was administered to convenience samples of faculty members and students of these six colleges of pharmacy (Baghdad, Basrah, Kufa, Duhok, Hawler and Sulaimani) from February to October 2015. Five-point Likert scales were used in the survey questionnaire, in addition to a sixth choice of "I do not know" $(1=$ strongly disagree, $2=$ disagree, $3=$ neutral, $4=$ agree $5=$ strongly agree, $6=\mathrm{I}$ do not know).

Iraqi and American faculty members reviewed the surveys for biased and unclear questions. The survey questionnaires were pretested (pilot study) in November and December 2014 to evaluate the reliability of new instruments. Iraqi faculty members teach and test academic courses in English. Hence, the questions were in English. The surveys had two formats: an electronic and paper version. The electronic version was administered through Qualtrics Survey Software (Qualtrics, Inc, Provo, UT). For most respondents, the survey links were administered electronically via email, personal Facebook messenger, and/or Facebook groups to convenience samples of students of the five-year bachelor programs (second year to fifth year students) and faculty members. Small numbers of respondents (28 students and 12 faculty members) received paper surveys, either because they had no email/ Facebook account or were not willing to share their email addresses. We excluded first year students because of their limited experience with using technology for academic purposes in the pharmacy school setting.

At the end of the survey, personal characteristics were collected from the students such as their age, gender, year of study, name of the university, whether they were working in a pharmacy or not, and whether they had a two-year pre-pharmacy diploma or not (Table 1). Personal characteristics were collected from the faculty members as well, such as their discipline, age, gender, years of experience, degree, management, number of courses they teach per semester and level of students (undergraduate, graduate or both) (Table 2). No incentives were offered to complete the survey. The survey was optional and anonymous.

This study received exemption from Institutional Review Board (IRB) of the University of Iowa and permission from the Iraqi schools and colleges of pharmacy.

The analyses were conducted using the Statistical Analysis System (SAS, version 9.3, SAS Inc., Cary, NC). We used logistic regression to identify predictors of use of Facebook and university email for daily academic communication, with separate models for students and faculty predicting use of each technology. For all four

Table 1. Student Demographic and Academic Characteristics

\begin{tabular}{|c|c|}
\hline Characteristic & $\mathbf{N}(\%)$ \\
\hline \multicolumn{2}{|c|}{ Age Category $(\mathrm{N}=485)$} \\
\hline 21 years & $171(35.3)$ \\
\hline 22 years & $154(31.8)$ \\
\hline 23 years & $107(23.0)$ \\
\hline $24-40$ years & $53(10.9)$ \\
\hline \multicolumn{2}{|c|}{ Gender $(\mathrm{N}=488)$} \\
\hline Female & $316(64.8)$ \\
\hline Male & $172(35.3)$ \\
\hline \multicolumn{2}{|c|}{ Academic Year $(\mathrm{N}=488)$} \\
\hline $2^{\text {nd }}$ & $14(2.9)$ \\
\hline $3^{\text {rd }}$ & $132(27.1)$ \\
\hline $4^{\text {th }}$ & $189(38.7)$ \\
\hline $5^{\text {th }}$ & $153(31.4)$ \\
\hline \multicolumn{2}{|c|}{ Have 2-year Pre-pharmacy Degree $(\mathrm{N}=484)$} \\
\hline Yes & $41(8.5)$ \\
\hline No & $443(91.5)$ \\
\hline \multicolumn{2}{|c|}{ Working in Pharmacy $(\mathrm{N}=485)$} \\
\hline Yes & $111(22.9)$ \\
\hline No & $374(77.1)$ \\
\hline \multicolumn{2}{|c|}{ University Name ( $\mathrm{N}=489)$} \\
\hline Baghdad & $26(5.3)$ \\
\hline Basrah & $55(11.3)$ \\
\hline Duhok & 80 (16.4) \\
\hline Hawler & $23(5.1)$ \\
\hline Kufa & $264(54.0)$ \\
\hline Sulaimani & $38(7.8)$ \\
\hline Other & $1(0.2)$ \\
\hline
\end{tabular}


American Journal of Pharmaceutical Education 2017; 81 (5) Article 89.

Table 2. Faculty Demographic and Academic Characteristics

\begin{tabular}{|c|c|}
\hline Characteristic & $\mathbf{N}(\%)$ \\
\hline \multicolumn{2}{|l|}{ Gender $(\mathrm{N}=126)$} \\
\hline Male & $77(61.1)$ \\
\hline Female & $49(38.9)$ \\
\hline \multicolumn{2}{|l|}{ Age $(\mathrm{N}=128)$} \\
\hline $25-29$ & $32(25.0)$ \\
\hline $30-34$ & $33(25.8)$ \\
\hline $35-39$ & $24(18.8)$ \\
\hline $40-44$ & $20(15.6)$ \\
\hline $45-60 \leq$ & $19(14.8)$ \\
\hline \multicolumn{2}{|c|}{ Management position $(\mathrm{N}=125)$} \\
\hline Yes & $69(53.91)$ \\
\hline No & $58(45.31)$ \\
\hline \multicolumn{2}{|c|}{ Years in practice $(\mathrm{N}=124)$} \\
\hline $1-5$ & $48(38.7)$ \\
\hline $6-10$ & $37(29.8)$ \\
\hline $11-15$ & $17(13.7)$ \\
\hline $16-20$ & $10(8.1)$ \\
\hline $21-40$ & $12(9.7)$ \\
\hline \multicolumn{2}{|c|}{ Academic Title $(\mathrm{N}=126)$} \\
\hline Full professor & $5(4.0)$ \\
\hline Associate professor & $7(5.6)$ \\
\hline Assistant professor & $16(12.7)$ \\
\hline Lecturer & $36(28.6)$ \\
\hline Assistant lecturer & $37(29.4)$ \\
\hline Adjunct instructor & $13(10.3)$ \\
\hline Other & $12(9.5)$ \\
\hline \multicolumn{2}{|c|}{ Type of Management position $(\mathrm{N}=48)$} \\
\hline Department Head & $27(56.3)$ \\
\hline Assistant Dean & $19(39.6)$ \\
\hline Dean & $2(4.2)$ \\
\hline \multicolumn{2}{|l|}{ Degree $(\mathrm{N}=128)$} \\
\hline Bachelor (BSc) & $23(18.0)$ \\
\hline Master (MSc) & $47(36.7)$ \\
\hline Doctorate $(\mathrm{PhD})$ & $52(40.6)$ \\
\hline Other & $6(4.7)$ \\
\hline \multicolumn{2}{|l|}{ University $(\mathrm{N}=127)$} \\
\hline Baghdad & $16(12.6)$ \\
\hline Kufa & $44(34.7)$ \\
\hline Sulaimani & $20(15.8)$ \\
\hline Basrah & $18(14.2)$ \\
\hline Hawler & $10(7.9)$ \\
\hline Duhok & $17(13.4)$ \\
\hline Other & $2(1.6)$ \\
\hline \multicolumn{2}{|l|}{ Student Level $(\mathrm{N}=128)$} \\
\hline Undergraduate & $94(73.4)$ \\
\hline Graduate & $6(4.7)$ \\
\hline Both & $28(21.9)$ \\
\hline \multicolumn{2}{|l|}{ Number of Courses } \\
\hline \multicolumn{2}{|c|}{ Taught per Semester $(\mathrm{N}=121)$} \\
\hline 1 & $25(20.7)$ \\
\hline 2 & $73(60.3)$ \\
\hline
\end{tabular}

(Continued)
Table 2. (Continued)

\begin{tabular}{lc}
\hline Characteristic & N (\%) \\
\hline 3 & $14(11.6)$ \\
4 or more & $9(7.4)$ \\
Department $(\mathrm{N}=121)$ & \\
Clinical Pharmacy & $28(23.1)$ \\
Pharmacology and Toxicology & $34(28.1)$ \\
Pharmacognosy and Natural Products & $6(5.0)$ \\
Pharmaceutical/Medicinal Chemistry & $19(15.7)$ \\
Pharmaceutics/Pharmaceutical Industry & $24(19.8)$ \\
Clinical Laboratories & $10(8.3)$ \\
Discipline (scientific background) (N=125) & \\
Pharmacy & $87(69.6)$ \\
Chemistry & $15(12.0)$ \\
Biology & $8(6.4)$ \\
Veterinary pathology & $3(2.4)$ \\
Physics & $3(2.4)$ \\
Others & $9(7.2)$ \\
\hline
\end{tabular}

logistic regression analyses, the outcome variable categories were collapsed from five (strongly disagree, disagree, neutral, agree and strongly agree) into binary responses (not agree vs agree) since some categories had low numbers of observations. The agree response consisted of agree and strongly agree while the not agree response compiled neutral, disagree and strongly disagree.

Participants with missing values for the outcome or predictor variables were excluded from logistic regression analyses. We excluded from the final regression and correlation analyses any participant who did not respond to the outcome variable and excluded those who chose answer " $6=\mathrm{I}$ do not know' for the TAM variable questions or outcome. Additionally, any respondents from universities other than the six main ones were excluded from the analyses (one student and two faculty members). Thus, the final regression models included 443 Facebook and 304 university email observations of students and 113 Facebook and 111 university email observations of faculty. Logistic regression analyses measured the association between the dependent variables (use of Facebook and university email for academic purposes) and six independent variables of TAM: Attitude Toward Using (ATU), Actual Technology Use (ACU), Facilitating Conditions (FC), Perceived Ease of Use (PEU), Perceived Usefulness (PU), and Behavioral Intention to Use (BIU), in addition to participant characteristics. We used Spearman correlations to measure the relationship between the two outcome variables within each of the participant populations. 


\section{American Journal of Pharmaceutical Education 2017; 81 (5) Article 89.}

To choose the best reduced model, each independent variable was included in bivariate regression analyses against the dependent variables. Then, we only included those significantly related to the outcome variables to reduce the number of independent variables included in multivariable models. Second, we used backward manual selection, deleting the variable(s) with the highest $p$ value in each model, with the goal of finding the model with the smallest Akaike Information Criterion (AIC) value (lower value means better quality model). In Table 3, "I do not know" responses were included in the dominator (agree + strongly agree/all responses including choice no. 6), but they were excluded from regression and correlation analyses.

\section{RESULTS}

The researchers received 595 student surveys, but only 489 were usable. The other 106 were missing responses on participant characteristics, which were at the end of the survey. Descriptive statistics are shown in Table 1 . The majority of student respondents were female $(65.8 \%)$ and more than half $(54.0 \%)$ were from the University of Kufa College of Pharmacy. Most (89.1\%) students were between 21 and 24 years old. The majority (77.1\%) were not working at a pharmacy and only $8.5 \%$ had two-year pre-pharmacy degrees (Table 1).

The majority (79\%) of student-respondents agreed that almost everyone in the college has a Facebook

Table 3. Survey Questionnaire According to TAM Variables and Percentage of Faculty and Students Who Agreed (agree and strongly agree) and Did Not Have an Opinion (I do not know)

\begin{tabular}{|c|c|c|c|c|}
\hline Survey Items & $\begin{array}{c}\text { Agreed } \\
\text { Faculty \% }\end{array}$ & $\begin{array}{l}\text { Faculty With } \\
\text { No Opinion \% }\end{array}$ & $\begin{array}{c}\text { Agreed } \\
\text { Students \% }\end{array}$ & $\begin{array}{c}\text { Students } \\
\text { With No } \\
\text { Opinion \% }\end{array}$ \\
\hline \multicolumn{5}{|l|}{ Questions Related to University Email Use } \\
\hline $\begin{array}{l}\text { University email saves time compared to personal email in } \\
\text { contacting faculty members (PU) }\end{array}$ & 49.3 & 6.2 & 54.5 & 15.0 \\
\hline Using university email is easy for $\mathrm{me}^{\mathrm{a}}(\mathrm{PEU})$ & 44.2 & 5.4 & 41.8 & 15.0 \\
\hline $\begin{array}{l}\text { I prefer using university email over personal email for } \\
\text { academic contacts (ATU) }\end{array}$ & 48.6 & 4.8 & 44.8 & 15.3 \\
\hline University email has all faculty email addresses (FC1) & 39.4 & 14.8 & 36.6 & 28.6 \\
\hline University email has all student email addresses (FC2) & 20.1 & 16.0 & 31.2 & 27.3 \\
\hline $\begin{array}{l}\text { I will try to use my university email instead of personal email } \\
\text { to contact faculty members (BIU) }\end{array}$ & 23.1 & 6.3 & 48.9 & 11.4 \\
\hline I use university email in my daily academic contact (ACU) & 28.5 & 4.9 & 26.9 & 10.6 \\
\hline \multicolumn{5}{|l|}{ Questions Related to Facebook Use } \\
\hline $\begin{array}{l}\text { Facebook can be used for communication and } \\
\text { announcements about courses and } \text { classes }^{\mathrm{a}}(\mathrm{PU} 1)\end{array}$ & 42.9 & 2.9 & 82.0 & 2.2 \\
\hline $\begin{array}{l}\text { Facebook allows me to reach students and faculty members } \\
\text { quickly (PU2) }\end{array}$ & 52.8 & 2.8 & 63.5 & 2.0 \\
\hline $\begin{array}{l}\text { I do not have any problems learning Facebook's features on } \\
\text { my own }^{\mathrm{b}} \text { (PEU1) }\end{array}$ & 66.9 & 3.5 & 81.4 & 2.5 \\
\hline I find it easy to use Facebook features ${ }^{\mathrm{a}, \mathrm{b}}$ (PEU2) & 71.1 & 2.8 & 82.0 & 2.1 \\
\hline $\begin{array}{l}\text { If I send Facebook friendship requests to my students/ } \\
\text { teacher(s), my request will be accepted (FC) }\end{array}$ & 57.1 & 14.3 & 64.6 & 11.4 \\
\hline Almost everyone in my college has a Facebook account (FC) & 62.1 & 13.6 & 79.0 & 4.2 \\
\hline $\begin{array}{l}\text { I love using Facebook because it facilitates communications } \\
\text { between teachers and students (ATU) }\end{array}$ & 47.1 & 2.2 & 73.1 & 3.1 \\
\hline $\begin{array}{l}\text { I will use Facebook to communicate with my students/ } \\
\text { classmates about class projects }^{\text {b }} \text { (BIU) }\end{array}$ & 31.4 & 1.4 & 76.8 & 1.7 \\
\hline \multicolumn{5}{|l|}{$\begin{array}{l}\text { I usually answer my students' questions through Facebook } \\
\text { (faculty) (ACU1) }\end{array}$} \\
\hline I usually ask my teachers through Facebook (students) & 38.1 & 2.2 & 38.3 & 4.1 \\
\hline I use my Facebook account for academic purposes ${ }^{\mathrm{b}}$ (ACU2) & 30.2 & 3.6 & 60.2 & 2.2 \\
\hline
\end{tabular}

Abbreviations: Behavioral Intention to Use (BIU), Perceived Usefulness (PU), Perceived Ease of Use (PEU), Attitude Toward Using (ATU), Facilitating Conditions (FC), Actual Technology Use (ACU)

${ }^{a}$ Adopted from Teo article with modifications. ${ }^{11}$

${ }^{\mathrm{b}}$ Adopted from Sánchez article with modifications. ${ }^{3}$

Survey participants responded $1=$ strongly disagree, $2=$ disagree, $3=$ neutral, $4=$ agree, $5=$ strongly agree, $6=\mathrm{I}$ do not know 


\section{American Journal of Pharmaceutical Education 2017; 81 (5) Article 89.}

account. A large percentage (60.2\%) had been using Facebook for academic purposes. Eighty-two percent of student-respondents agreed Facebook is easy to use and only $41.8 \%$ perceived university email as easy to use. Thirty-one percent agreed that university email has all student email addresses. Although around $45 \%$ of student respondents preferred using university email over personal email for academic communications, only a small percent (26.9\%) of them had used university email (Table $3)$. In contrast, $60 \%$ of student-respondents had used Facebook for academic purposes (Table 3).

Spearman correlation analysis showed a significant $(p \leq .05)$ positive correlation $(\mathrm{rho}=.26)$ between student responses on use of Facebook and university email for academic communication. Among 17 independent variables examining student characteristics and Facebook use for academic purposes, only three had significant associations with the outcome variable. The binary logistic regression analysis showed that a one-unit increase in the attitude variable (love to use Facebook for communication between students and teacher) was associated with 1.3 times higher odds of choosing "agree" to using Facebook for academic purposes after controlling other variables $(p=.04)$ (Table 4A). Likewise, a one-unit increase in willingness to use a Facebook account to communicate with other classmates about class projects was associated with 1.5 times higher odds of choosing an "agree" response for using Facebook for academic purposes after controlling other covariates (Table 4A). In other words, the student-respondents with a positive Attitude Toward Using and Behavioral Intention to Use were more likely to use Facebook for academic purposes.
In addition to student attitude and intention toward using Facebook, some universities were significantly different regarding using Facebook for academic purposes. The students of Basrah and Duhok Colleges of Pharmacy were significantly less likely (60\% and 50\% lower odds respectively) to agree with using Facebook for academic purposes compared to students of the University of Kufa. Similarly, students of the universities of Hawler and Sulaimani were less likely to use Facebook for academic purposes compared to the University of Kufa students, but these differences were not significant $(p \geq .05)$. Students working in pharmacies had greater odds $(\mathrm{OR}=1.35)$ of using Facebook for academic purposes than non-working students, but this difference was not significant $(p \geq .05)$ (Table 4A).

Four independent variables in the logistic regression analysis of student university email had significant positive relationships with using university email for academic purposes (outcome variable) (Table 5A). The results showed that when the variable "university email easiness" increased by one unit, students had 1.88 times greater odds of choosing "agree" for the outcome variable (university email for academic contacts). Similarly, student-respondents who perceived a higher university email preference, university email usefulness and university email intention to use were more likely to use university email for daily academic communications (with ORs of $1.71,2.98$ and 1.84 respectively) (Table 5A).

One hundred and forty-seven full-time faculty members responded, but only 128 surveys were usable. Faculty members $(61.1 \%)$ were males; ranged in age from 25 to 39 years; and $68.6 \%$ had one to 10 years of practice. Faculty members had a $\mathrm{PhD}(40.6 \%)$ or Master degree

Table 4A. Logistic Regression Results of Factors Associated With Students Using Facebook for Academic Purposes ${ }^{\mathrm{e}}$

\begin{tabular}{|c|c|c|c|c|}
\hline \multirow{2}{*}{$\frac{\text { Independent Variables }}{\text { Facebook useful }^{\mathrm{a}}}$} & \multirow{2}{*}{$\begin{array}{c}\begin{array}{c}\text { Odds Ratio } \\
\text { Estimate }\end{array} \\
0.93\end{array}$} & \multicolumn{2}{|c|}{$\begin{array}{c}95 \% \text { Wald } \\
\text { Confidence Limits }\end{array}$} & \multirow{2}{*}{$\frac{p \text { Value }}{.55}$} \\
\hline & & 0.72 & 1.19 & \\
\hline Facebook easy ${ }^{\mathrm{b}}$ & 1.33 & 0.98 & 1.82 & .072 \\
\hline Facebook love ${ }^{c}$ & 1.33 & 1.02 & 1.74 & $.035^{\mathrm{f}}$ \\
\hline Facebook will ${ }^{\mathrm{d}}$ & 1.53 & 1.20 & 1.96 & $.000^{\mathrm{f}}$ \\
\hline Baghdad vs Kufa & 0.50 & 0.21 & 1.21 & .124 \\
\hline Basrah vs Kufa & 0.40 & 0.20 & 0.78 & $.007^{\mathrm{f}}$ \\
\hline Duhok vs Kufa & 0.51 & 0.29 & 0.90 & $.020^{\mathrm{f}}$ \\
\hline Hawler vs Kufa & 0.44 & 0.18 & 1.09 & .074 \\
\hline Sulaimani vs Kufa & 0.56 & 0.25 & 1.29 & .175 \\
\hline Pharmacy Work: yes/no & 1.35 & 0.81 & 2.27 & .252 \\
\hline
\end{tabular}

C-statistic $=0.712 ; \mathrm{N}=442$

${ }^{\mathrm{a}}$ Facebook useful: Facebook can be used for communication and announcement about courses and classes

${ }^{b}$ Facebook easy: Using Facebook email is easy for me

${ }^{c}$ Facebook love: I love using Facebook because it facilitates communications between teachers and students

${ }^{\mathrm{d}}$ Facebook will: I will use Facebook to ask class-related questions to my teacher(s)

${ }^{\mathrm{e}}$ Facebook academic (outcome): Using Facebook for academic purposes

${ }^{\mathrm{f}}$ Significant $(\leq .05)$ 


\section{American Journal of Pharmaceutical Education 2017; 81 (5) Article 89.}

(36.7\%) with others indicating lecturer $(28.6 \%)$ or assistant lecturer (29.4\%) academic titles. Faculty-respondents $(69.6 \%)$ had a pharmacy background and more than half $(53.9 \%)$ had management duties such as dean, dean assistants and department heads. The University of Kufa had the highest percent of faculty-respondents (34.7\%) and Hawler had the lowest percent of faculty-respondents (7.9\%). Pharmacology (28.1\%) and clinical pharmacy (23.1\%) departments had the highest share among the six college departments. Faculty members (73.4\%) had been teaching undergraduate pharmacy students and usually taught two courses $(60.3 \%)$ per semester (Table 2). Adjunct instructors are those faculty members with a BSc degree and at an early stage of their faculty positions.

Faculty respondents (52.1) agreed with the question stating almost everyone in the college has a Facebook account. Thirty percent had used Facebook to post class announcements and a similar proportion $(28.5 \%)$ had used university email in their daily academic communications. The majority of faculty $(71.1 \%)$ believed Facebook was easy to use and less than half (44.2\%) perceived university email as easy to use (Table 3 ). Spearman correlation analysis showed a significant $(p \leq .05)$ positive correlation $(\mathrm{rho}=.21)$ between the two outcome variables of the faculty members (using Facebook and university email for academic communications).

Three out of four independent variables included in the final reduced model had significant associations with the outcome variable (using Facebook for academic purposes). When Facebook usefulness responses increased one unit, the faculty had greater odds of agreeing with using Facebook for academic purposes $(\mathrm{OR}=2.37)$. Similarly, intention to use had a significant positive relationship $(\mathrm{OR}=5.7)$ with the outcome variable. Female faculty members were significantly less likely $(\mathrm{OR}=.2)$ to agree with using Facebook for academic purposes than males (Table 4B). No other faculty characteristics had significant associations with the outcome variable.
One-fifth $(20 \%)$ of faculty-respondents agreed that university email has all students' email addresses and $39 \%$ agreed that university email has all faculty members' email addresses. Only $28.5 \%$ of the facultyrespondents used university email in their daily academic communication.

Unlike the Facebook results, no faculty demographic characteristic had a significant relationship with use of university email for daily academic communication. Similar to student results, perceived usefulness, attitude toward using and behavioral intention to use had significant positive associations with the outcome variable (Table 4B). A one unit increase in university email preference (I prefer using university email over personal email for academic contacts) was associated with 2.16 times greater odds of agreeing with using university email for daily academic communication. University email usefulness (OR 1.97) and university email intention to use (OR 2.11) were significant predictors of use for academic purposes.

The four logistic regression analyses (Tables 4 and 5B) showed two to four of the TAM independent variables had significant association with the outcome variables (ACU). BIU had significant positive association across the four regression models. ATU had significant positive relationship in three logistic regression analyses (Tables 4A, 5A and 5B). PU had significant positive relationship in three logistic regression models (Tables $4 \mathrm{~B}, 5 \mathrm{~A}$ and $5 B)$. PEU had a significant relationship only in students using university email (Table 5A). University and gender were the only two individual characteristics that had significant association with using Facebook for academic purposes in the students and faculty members respectively. The FC had non-significant ( $p \geq .05)$ associations in all four logistic regression analyses.

\section{DISCUSSION}

Electronic faculty-student communication modes facilitate academic discussion and save time outside the

Table 4B. Logistic Regression Results of Factors Associated With Faculty Using Facebook for Academic Purposes

\begin{tabular}{|c|c|c|c|c|}
\hline \multirow{2}{*}{$\frac{\text { Independent variables }}{\text { Facebook useful }^{\mathrm{a}}}$} & \multirow{2}{*}{$\begin{array}{c}\begin{array}{c}\text { Odds Ratio } \\
\text { Estimate }\end{array} \\
2.37\end{array}$} & \multicolumn{2}{|c|}{$\begin{array}{c}\text { 95\% Wald } \\
\text { Confidence Limits }\end{array}$} & \multirow{2}{*}{$\frac{p \text { Value }}{.007^{\mathrm{d}_{*}}}$} \\
\hline & & 1.26 & 4.48 & \\
\hline Facebook will $^{\mathrm{c}}$ & 5.47 & 2.32 & 12.85 & $<.000^{\mathrm{d}}$ \\
\hline Gender: female vs male & 0.24 & 0.06 & 0.93 & $.039^{\mathrm{d}}$ \\
\hline
\end{tabular}

C-statistic: $0.937 ; \mathrm{N}=114$

${ }^{\mathrm{a}}$ Facebook useful: Facebook enables me to post announcements to my students

${ }^{\mathrm{b}}$ Facebook request: If I send Facebook friendship request to my students, my request will be accepted

${ }^{c}$ Facebook will: I will use Facebook to communicate with my students about class projects

${ }^{\mathrm{d}}$ Significant $(p \leq .05)$

Outcome variable (agree vs disagree) $=$ Facebook academic: I use my Facebook account to post class announcements to my students 


\section{American Journal of Pharmaceutical Education 2017; 81 (5) Article 89.}

Table 5A. Logistic Regression Results of Factors Associated With Students Using University Email

\begin{tabular}{lccrr}
\hline Independent variables & Odds Ratio Estimate & \multicolumn{2}{c}{$\begin{array}{c}\mathbf{9 5 \%} \text { Wald } \\
\text { Confidence Limits }\end{array}$} & $\boldsymbol{p}$ Value \\
\hline University email easy $^{\mathrm{a}}$ & 1.88 & 1.26 & 2.82 & $.002^{\mathrm{e}}$ \\
University email prefer $^{\mathrm{b}}$ & 1.71 & 1.19 & 2.46 & $.003^{\mathrm{e}}$ \\
University email usefulc $^{\mathrm{c}}$ & 2.98 & 2.09 & 4.25 & $<.000^{\mathrm{e}}$ \\
University email will $^{\mathrm{e}}$ & 1.84 & 1.23 & 2.77 & $.003^{\mathrm{e}}$ \\
2 yrs. pre-pharmacy (y/n) & 2.33 & 0.79 & 6.85 & .124 \\
\hline
\end{tabular}

$\mathrm{N}=302 ;$ C-statistic $=0.886$

${ }^{a}$ University email easy: Using university email is easy for me

${ }^{b}$ University email prefer: I prefer using university email over personal email for academic contacts

${ }^{c}$ University email useful: University email has all student email addresses

${ }^{\mathrm{d} U n i v e r s i t y ~ e m a i l ~ w i l l: ~ I ~ w i l l ~ u s e ~ u n i v e r s i t y ~ e m a i l ~ f o r ~ a c a d e m i c ~ c o n t a c t s ~}$

${ }^{\mathrm{e}}$ Significant $(p \leq .05)$

classroom. There is no official university electronic communication mode between Iraqi colleges of pharmacy faculty and students. We investigated the use of available social media, Facebook, as an alternative given the absence of adequate university email infrastructure. A study involving four schools and colleges of pharmacy in Ohio, revealed that the majority (89\%) of faculty declined friendship requests from current students on Facebook, and only a few (12\%) accepted friendship requests from students or used Facebook for academic purposes. ${ }^{14}$ In contrast, more than half (57\%) of Iraqi Pharmacy faculty accepted their current student friendship requests on Facebook. Because an official university email is available in the US to connect students and faculty, they believe there is no need to employ social media for academic communications. Iraqi faculty may feel Facebook can fill the gap of not having a university email.

Approximately two-thirds of the student-respondents were female. The majority (64.8\%) of students at Iraqi schools and colleges of pharmacy are females because they generally score higher than males in their high school's standardized exam (Baccalaureate). Thus, girls have a better chance of being accepted by highly ranked medical, pharmacy, and dentistry colleges. Because the Iraqi Ministry of Higher Education does not require a pre-pharmacy degree to apply for pharmacy colleges, only a small portion $(8.5 \%)$ of pharmacy-student respondents had a two-year pre-pharmacy degree (Table 1). Full-time pharmacy students usually have a full academic schedule from 8:30 am to $3: 30 \mathrm{pm}$ five days a week, resulting to only a small percent $(22.9 \%)$ of students working in community pharmacies. Iraqi colleges of pharmacy offer five-year bachelor programs for students with a high school diploma. The age range of college students is typically 19 to 23 years. Thus, most (90.1\%) student-participant were 21- to 23-years old. The University of Kufa had the second (after Baghdad) highest number of enrolled pharmacy students in 2014/ 2015 academic year and it contributed to more than half of student-respondents (Table 1).

Schools and colleges of pharmacy in Iraq are usually independent colleges wherein students take almost all their courses within the same college. This characteristic explains the availability of faculty members from more

Table 5B. Logistic Regression Results of Factors Associated With Faculty Using University Email

\begin{tabular}{lcccc}
\hline Independent variables & $\begin{array}{c}\text { Odds Ratio } \\
\text { Estimate }\end{array}$ & \multicolumn{2}{c}{$\begin{array}{c}\mathbf{9 5 \%} \text { Wald } \\
\text { Confidence Limits }\end{array}$} & $\boldsymbol{p}$ Value \\
\hline University email save $^{\mathrm{a}}$ & 0.61 & 0.33 & 1.11 & .106 \\
University email prefer $^{\mathrm{b}}$ & 2.19 & 1.22 & 3.82 & $.008^{\mathrm{f}}$ \\
University email useful $^{\mathrm{c}}$ & 1.97 & 1.23 & 3.17 & $.005^{\mathrm{f}}$ \\
University email will $^{\mathrm{d}}$ & 2.11 & 1.23 & 3.63 & $.007^{\mathrm{f}}$ \\
No. of courses/semester $^{\mathrm{f}}$ & 0.78 & 0.43 & 1.40 & .399 \\
\hline
\end{tabular}

C-statistic: $0.85 ; \mathrm{N}=112$

${ }^{a}$ University email save: University email saves time compared to personal email in contacting other faculty members

${ }^{b}$ University email prefer: I prefer using university email over personal email for academic contacts

${ }^{c}$ University email useful: University email has all faculty member email addresses

${ }^{\mathrm{d}}$ University email will: I will try to use my university email instead of personal email to contact other faculty members

University email academic (agree vs disagree): I use university email in my daily academic contacts

${ }^{\text {f }}$ Significant $(p \leq 0.05)$ 


\section{American Journal of Pharmaceutical Education 2017; 81 (5) Article 89.}

than five different disciplines other than pharmacy, though pharmacy was the most common background of faculty participants (Table 2). The percent of facultyrespondents with more than 10 years in practice was around one-third because most experienced professors either retire at age 65, immigrated and left Iraq after 2003 or did not respond. The same reasons apply to a minority $(22 \%)$ of faculty-respondents with high academic titles (full professor, associate professor and assistant professor) (Table 2). Most (73.4\%) facultyrespondents had been teaching undergraduate students because they do not have the required doctoral degree and academic titles (professor, associate or assistant professor) that allow them to teach graduate students.

According to the findings of both faculty and student surveys, more than three-quarters of students and twothirds of faculty perceived Facebook as easy to use. In contrast, less than half of each group perceived university email as easy to use (Table 3). Ease of use may incentivize faculty to use Facebook for academic purposes over email. For example, faculty members can use Facebook to distribute a class announcement just by posting on their profile; while to use email, faculty members need to collect and save all student email addresses that are not available in university email. Additionally, students may browse Facebook more frequently than check their emails.

Table 4A shows significant differences in the use of Facebook for academic purposes between university of Kufa and the universities of Duhok and Basrah while the differences with the other three universities are not significant. This may be due to the difference in the city cultures. Those three universities are located in three different provinces across Iraq. Duhok province is located in the northern region of Iraq (Kurdistan) and people who live there speak the Kurdish language. Al-Kufa University is located in the middle province (Al-Najaf) and Basrah in the south, and people in both provinces speak Arabic. Al-Najaf city is a more conservative city (holy city) and female students might tend to ask questions electronically rather than face to face. Additionally, almost all the students of Al-Kufa college of pharmacy have a Facebook account, send friendship invitations to their instructors and ask course-related questions via Facebook more frequently than the students at both Basrah and Duhok colleges. In our study, $38 \%$ of faculty members have answered student questions via Facebook. On the other hand, the Ohio study found a small number of faculty using Facebook for academic online discussions. ${ }^{14}$

Students who are Facebook friends with their current instructors is socially accepted behavior in the Iraqi culture. Nevertheless, using Facebook for academic communications may harm professional reputations, risk privacy of the faculty-student conversations and negatively influence faculty credibility. ${ }^{9,15}$ Additionally, it blends the personal life (with family and friends) and academic life (with instructors and students) and this may negatively impact the faculty-student academic relationship. Using a closed Facebook group for each course may be an alternative to maintain privacy. A closed group does not require students to be friends with their current instructors.

The unstable security conditions within Iraq may have negatively influenced technical maintenance for university electronic communications such as email. In addition to unrest, the cost of adapting advance technologies may be a second barrier, particularly in public universities that are government-funded and apply no fees. In our study, low percentages of faculty members and students had used university email for academic purposes (Table 3). University of Kufa College of Pharmacy was the only college providing university email to its students. Availability of technologies may depend on university resources. In contrast, Stolte and colleagues found $90 \%$ of pharmacy students in the US are comfortable with using technologies for academic purposes, including university email. ${ }^{16}$

The correlation analyses showed significant positive correlation between faculty and student use of university email and use of Facebook for academic communications. The large portion of young faculty may contribute to the use of electronic communications (Facebook and email). The TAM theoretical framework guided the study and survey questionnaires. After testing TAM to investigate which factors influence using Facebook for academic purposes, only three (intention to use, attitude and perceived usefulness) out of the six TAM concepts had significant association with the outcome variable across the two populations and the two communication technologies. The facilitating conditions variable that Teo found to be important was not significant in all four logistic regression analyses. ${ }^{11} \mathrm{We}$ added personal characteristic variables to modified TAM and only two of these characteristics (university and gender) had significant associations with using Facebook for academic purposes. Universities are located in culturally different cities and may vary in use of Facebook for academic purposes. Female faculty members were less likely to use Facebook for academic purposes than male faculty. For cultural reasons, Iraqi women are generally less active on Facebook than men, and this may extend to academic use.

For faculty members, the sample size was not large enough to give significant results for a larger number of variables in the regression analyses. The sample was one 


\section{American Journal of Pharmaceutical Education 2017; 81 (5) Article 89.}

of convenience and that may weaken the generalization of the findings. However, the study included six colleges from six different provinces from four different geographical areas across Iraq. Eighty-two percent of the student-respondents and $87 \%$ of the faculty-respondents submitted complete surveys. Responding to electronic surveys is fairly new for Iraqis. This unfamiliarity or survey fatigue may have influenced response rates $(18 \%$ and 13\%). Using an electronic survey had some accessibility limitations, particularly for students because most of them were not using university email. In addition, use of an electronic survey could have biased the results toward responses of those more comfortable with technology. Nevertheless, we offered paper surveys for those who agreed to participate and who may not have neither email nor Facebook account accounts.

\section{CONCLUSION}

Faculty members and students in select Iraqi schools and colleges of pharmacy use Facebook more than university email for their daily academic communications, and consider Facebook as easy to use. Less than one-third of faculty members use university email for academic purposes. Students use Facebook for academic purposes twice as much as their faculty members. Three (intention to use, attitude and perceived usefulness) out of the six TAM factors had significant associations with use of both communication technologies. Since, Facebook is perceived as easy to use for academic purposes, it might be used more widely among instructors who perceive advantages of chat functions and other interactive features over technologies available at their schools.

We recommend use of closed groups if Facebook is used to replace or augment other academic technologies to bypass concerns related to privacy. Facebook can fill the gap of low access to university email by serving as an electronic communication mode between university faculty and students. Iraqi universities need to implement university email containing all faculty and student addresses to avoid any ethical concerns related to using social media for academic communications.

\section{REFERENCES}

1. Zare-ee A. University teachers' views on the use of information communication technologies in teaching and research. Turkish Online J Educ Tech. 2011;10(3):318-327.

2. Arab Social Media Influencial Summit. Arab Social Media Report (2015). https://www.wpp.com/govtpractice/ /media/wppgov/files/ arabsocialmediareport-2015.pdf

3. Arteaga Sánchez R, Cortijo V, Javed U. Students' perceptions of Facebook for academic purposes. Comp Educ. 2014;70:138-149.

4. Roblyer MD, McDaniel M, Webb M, Herman J, Witty JV.

Findings on Facebook in higher education: A comparison of college faculty and student uses and perceptions of social networking sites. Internet Higher Educ. 2010;13(3):134-140.

5. Hall M, Hanna LA, Huey G. Use and views on social networking sites of pharmacy students in the United Kingdom. Am J Pharm Educ. 2013;77(1):Article 9.

6. Pawasauskas J, Matson KL, Youssef R. Transitioning to computerbased testing. Curr Pharm Teach Learn. 2014;6(2):289-297.

7. Waycott J, Bennett S, Kennedy G, Dalgarno B, Gray K. Digital divides? Student and staff perceptions of information and communication technologies. Comp Educ. 2010;54(4):1202-1211. 8. DiVall MV, Hayney MS, Marsh W, et al. Perceptions of pharmacy students, faculty members, and administrators on the use of technology in the classroom. Am J Pharm Educ. 2013;77(4):Article 75.

9. Mazer JP, Murphy RE, Simonds CJ. I'll see you on Facebook: the effects of computer-mediated teacher self-disclosure on student motivation, affective learning, and classroom climate. Comm Educ. 2007;56(1):1-17.

10. Hsiao JL, Chen RF. Critical factors influencing physicians' intention to use computerized clinical practice guidelines: an integrative model of activity theory and the technology acceptance model. BMC Med Inform Decis Mak. 2015;16(1):3.

11. Teo T. Factors influencing teachers' intention to use technology: model development and test. Comp Educ. 2011;57(4):2432-2440.

12. Al-Jumaili AA, Hussain SA, Sorofman B. Pharmacy in Iraq: history, current status, and future directions. Am J Health Syst Pharm. 2013;70(4):368-372.

13. University of Basrah. http://www.uobasrah.edu.iq/. Accessed April 7, 2014.

14. Metzger AH, Finley KN, Ulbrich TR, McAuley JW. Pharmacy faculty members' perspectives on the student/faculty relationship in online social networks. Am J Pharm Educ. 2010;74(10):Article 188. 15. Cain J. Online social networking issues within academia and pharmacy education. Am J Pharm Educ. 2008;72(1):Article 10. 16. Stolte SK, Richard C, Rahman A, Kidd Rtable 1S. Student pharmacists' use and perceived impact of educational technologies. Am J Pharm Educ. 2011;75(5):Article 92.

17. Davis FD, Bagozzi RP, Warshaw PR. User acceptance of computer technology: a comparison of two theoretical models. Manage Sci. 1989;35(8):982-1003. 